\title{
NILAI TAMBAH CORPORATE SOCIAL RESPONSIBILITY DAN INTELLECTUAL CAPITAL: SEBUAH PERSPEKTIF FOUR VALUE ASSESSMENT
}

\author{
Mirna Amirya \\ Fakultas Ekonomi dan Bisnis Universitas Brawijaya Malang \\ No Telepon: 081334068189
}

\begin{abstract}
This paper described the added value of Corporate Social Responsibility (CSR) and Intellectual Capital (IC) viewed from the perspective of four value assessment. Four value assessment consisted of economic performance, reputation value, parenting advantage, and spiritual value. The conclusion showed that based on the perspective of four value assessment, added value of economic performance used the formula of Economic Value Added (EVA) for CSR and Value Added Intellectual Capital (VAIC) for IC, reputation value used share prices and reputation quotient, parenting advantage used the company's strategy, and spiritual value used charity value.
\end{abstract}

Keywords: corporate social responsibility, intellectual capital, added value of four value assessment

\section{PENDAHULUAN}

Informasi yang sering muncul saat ini adalah informasi tentang tanggung jawab sosial perusahaan atau Corporate Sosial Responsibility (CSR) dan Intellectual Capital (IC). Wacana tersebut muncul dilandasi pemikiran bahwa CSR terkait dengan keberadaan perusahaan yang tidak terlepas dari lingkungannya. Sedangkan pemikiran IC dipandang sebagai bagian integral dari perusahaan dalam proses penciptaan nilai (value creation) dan mempertahankan keunggulan kompetitif perusahaan (Bollen et al., 2005). Pada intinya, setiap tindakan yang diambil perusahaan berdampak nyata terhadap nilai perusahaan.

Gagasan CSR dan IC menekankan bahwa kegiatan perusahaan bukan sekedar kegiatan ekonomi semata, yaitu menciptakan laba demi kelangsungan usaha, melainkan juga terkait tanggungjawabnya terhadap sosial dan lingkungan serta aset tidak berwujud perusahaan (sumber daya manusia, inovasi, pelanggan, maupun teknologi). Dasar pemikirannya adalah bahwa pemaksimalan laba tidak secara universal lagi diterima (Gray et al., 1995) serta menggantungkan semata-mata pada kesehatan finansial tidak menjamin perusahaan akan tumbuh secara berkelanjutan (Yuliana et al., 2008). 
CSR digambarkan sebagai ketersediaan informasi keuangan dan nonkeuangan berkaitan dengan interaksi organisasi dengan lingkungan fisik dan lingkungan sosialnya, yang dapat dibuat dalam laporan tahunan perusahaan atau laporan sosial terpisah (Yuliana et al., 2008). CSR merupakan kewajiban setiap organisasi bisnis atau perusahaan untuk ikut serta dalam kegiatan yang bertujuan melindungi serta meningkatkan kesejahteraan secara keseluruhan.

Analisis IC sendiri masih merupakan satu topik penting dalam penelitian pengungkapan sukarela perusahaan (Parker, 2007). Banyak perusahaan yang semakin menyadari pentingnya IC sehingga perusahaan diharapkan tidak hanya memberikan informasi dari aset berwujud (tangible assets) tetapi juga dari aset tidak berwujud (intangible assets) (Wright et al., 2001).

CSR dan IC mempengaruhi jalan suatu perusahaan untuk beroperasi. Konsep CSR dan IC merupakan tuntutan dan harapan dari berbagai stakeholder. Sementara, perusahaan menuntut manajer untuk bertindak secara ekonomi dan rasional. Hal tersebut menimbulkan dilema berbagai pihak sehingga perlu adanya penciptaan nilai dari berbagai stakeholder untuk dapat dimasukkan ke dalam keputusan bisnis.

Pembahasan tentang nilai tambah CSR pernah dilakukan oleh Kim dan Erik (2003). Mereka membahas perspektif triple value assessment yang terdiri dari kinerja ekonomi, nilai reputasi, dan keunggulan parenting terkait aplikasinya pada lima perusahaan yang memiliki perbedaan karakter.

Makalah ini menggunakan perspektif four value assessment untuk mendeskripsikan penentuan nilai tambah CSR dan IC. Perspektif four value assessment terdiri dari kinerja ekonomi, nilai reputasi, keunggulan parenting, dan nilai spiritual. Dari four value assessment yang ada, perspektif nilai spiritual merupakan pengembangan makalah ini.

\section{PEMBAHASAN}

\section{Corporate Social Responsibility (CSR)}

Sebagai suatu organisasi bisnis perusahaan yang hidup dan berkembang di tengah-tengah masyarakat maka dianggap sebagai bagian dari lingkungan masyarakat tersebut. Dengan demikian suatu perusahaan tidak terlepas dari tanggung jawab, baik kepada dirinya sendiri maupun kepada lingkungannya. CSR kepada lingkungan diwujudkan dengan ikut sertanya perusahaan dalam menyelesaikan masalah-masalah sosial, hal ini sesuai dengan harapan sebagian 
besar masyarakat yang menginginkan perusahaan memiliki respon positif terhadap lingkungan dengan melibatkan program-program sosial sebagai bagian dari aktivitas bisnisnya (Rajafi, 2007).

Budiarsi (2005) menunjukkan beberapa definisi mengenai CSR yang dikemukakan oleh beberapa penelitian sebelumnya antara lain:

"CSR merupakan praktek bisnis transparan, yang didasarkan pada nilai-nilai etika, dengan memberikan perhatian pada karyawan, masyarakat dan lingkungan, serta dirancang untuk dapat melestarikan masyarakat secara umum dan juga para pemegang saham" (CSRwire, 2005).

"CSR adalah penerimaan manajemen terhadap kewajiban untuk mempertimbangkan laba, kepuasan pelanggan, dan kesejahteraan sosial sebagai nilai yang sepadan dalam mengevaluasi kinerja perusahaan" (Boone \& Kurtz, 2002).

Menurut Porter dalam Budiarsi (2005), CSR bukanlah suatu tujuan, tetapi merupakan suatu strategi. Dari perspektif ini, maka CSR bukanlah suatu pilihan, tetapi merupakan suatu langkah dalam merumuskan strategi (strategy formulation). Pada saat ini perusahaan seharusnya melakukan investasi di bidang CSR sebagai bagian dari strategi bisnisnya agar dapat lebih bersaing. Lebih lanjut yang menjadi perhatian Porter adalah umumnya perusahaan baru bereaksi jika ada sesuatu masalah yang timbul, jadi CSR dianggap bukanlah merupakan suatu pemikiran strategik yang terintegrasi. Jika hal ini terjadi maka memang merupakan sesuatu yang dianggap sebagai "wasting shareholder money", sehingga tidak sustainable bagi perusahaan untuk jangka panjang. Perusahaan seharusnya bersifat proaktif mengintegrasikan inisiatif sosialnya dalam strategi bersaing bisnisnya. Bukan berarti perusahaan dunia bisnis harus berusaha menyelesaikan semua masalah sosial; hal ini sesuatu yang tidak mungkin. Perusahaan tentunya berperan untuk memilih dan memilah mana yang sesuai dengan konteks persaingan perusahaan. Perusahaan yang tanggap terhadap masalah lingkungan, perlu melakukan beberapa tahapan yaitu: perusahaan harus mengetahui dan menyadari adanya permasalahan; kemudian perusahaan berusaha mempelajari dan memahami masalah; selanjutnya perusahaan mempertimbangkan berbagai cara aktivitas untuk menangani 
masalah tersebut; dan diakhiri dengan tindakan pelaksanaan pemecahan masalah.

Gray et al., (1995) mengemukakan beberapa teori yang melatarbelakangi perusahaan untuk melakukan informasi sosial, yaitu:

\section{Decision Usefulness Studies}

Teori ini memasukkan para pengguna laporan akuntansi yang lain, tidak hanya para investor ke dalam kriteria dasar pengguna laporan akuntansi sehingga suatu pelaporan akuntansi dapat berguna untuk pengambilan keputusan ekonomi oleh semua unsur pengguna laporan tersebut. Beberapa peneliti menemukan bukti bahwa informasi sosial dibutuhkan oleh pengguna. Studi tersebut meminta para banker, analis, dan pihak lain yang terlibat untuk memberikan peringkat terhadap informasi akuntansi. Hasil menunjukkan bahwa informasi akuntansi tersebut tidak terbatas pada informasi yang telah dikenal selama ini, melainkan juga memuat informasi lain yang relatif baru dalam wacana akuntansi.

\section{Economic Theory Studies}

Studi ini berdasarkan economic agency theory. Teori tersebut membedakan antara pemilik perusahaan dengan pengelola perusahaan dan menyiratkan bahwa pengelola perusahaan harus memberikan laporan pertanggungjawaban atas segala sumber daya yang dimiliki dan dikelolanya kepada pemilik perusahaan. Selanjutnya, frase pemilik perusahaan mengalami perkembangan lebih lanjut, tidak hanya pemilik modal (shareholder), tapi juga meluas ke unsur stakeholders lainnya, yaitu masyarakat luas termasuk pemerintah dan lingkungan alam. Hal tersebut menuntut perusahaan untuk membuat pelaporan yang lengkap agar mampu memenuhi kebutuhan informasi bagi stakeholders tersebut.

\section{Social and Political Studies}

Sektor ekonomi tidak dapat dipisahkan dan terlepas dari kehidupan politik, sosial, dan kerangka institusional tempat ekonomi berada. Studi sosial dan politik mencakup dua teori utama, yaitu: Pertama, stakeholder theory yang mengasumsikan bahwa eksistensi perusahaan ditentukan oleh para stakeholders. Fokus utama dalam teori ini yaitu bagaimana perusahaan memonitor dan merespon kebutuhan para stakeholders-nya. Kedua, legitimacy theory menyatakan bahwa perusahaan harus dapat menyesuaikan diri dengan sistem nilai yang telah diterapkan masyarakat. 
Usaha perusahaan antara lain diwujudkan melalui pengungkapan sosial. Hal tersebut dilaksanakan dengan tujuan agar aktivitas dan keberadaan perusahaan terlegitimasi di mata masyarakat.

Selain itu, menurut Yuliana et al., (2008), teori-teori lain yang mendukung praktek pengungkapan sosial, yaitu teori kontrak sosial. Teori tersebut menyatakan bahwa perusahaan sebagai bagian yang tidak terpisahkan dari suatu komunitas.

CSR diungkapkan di dalam laporan yang disebut Sustainability Reporting. Sustainability Reporting meliputi pelaporan mengenai ekonomi, lingkungan dan pengaruh sosial terhadap kinerja organisasi. Darwin dalam Anggraini (2006) menyatakan bahwa Corporate Sustainability Reporting terbagi menjadi 3 kategori yaitu kinerja ekonomi, kinerja lingkungan, dan kinerja sosial. Sementara GRI (2006:24) membagi pengungkapan CSR dalam enam dimensi, yaitu lingkungan, ekonomi, hak asasi, ketenagakerjaan, tanggung jawab produk, dan kemasyarakatan.

\section{Intellectual Capital (IC)}

Menurut Belkaoui (2003), intellectual capital (IC) dibangun oleh dua pandangan yaitu pandangan berbasis sumber daya (resource-based view) dan pandangan stakeholder. Pandangan berbasis sumber daya menyatakan bahwa keunggulan bersaing (competitive advantages) tidak hanya dicapai melalui kombinasi produksi dengan pasar, tetapi lebih ditentukan oleh sumber daya yang dimiliki perusahaan, khususnya yang berupa intangible asset atau hidden asset. Pandangan teori stakeholder menyatakan bahwa perusahaan bertanggung jawab kepada para stakeholders, tidak hanya pemegang saham. Teori stakeholder lebih mempertimbangkan kebutuhan para stakeholders-nya.

Sampai saat ini belum ada definisi IC yang diterima secara luas. Beberapa peneliti berusaha menggali definisi IC. Bontis $(1998,2001)$, dan Mouritsen et al., (2001) menyatakan bahwa IC merupakan interaksi dari human capital, structural capital, dan customer capital. Sementara Guthrie et al., (2004) menunjukkan klasifikasi lain, di mana structural capital dibagi menjadi organizational capital dan customer capital.

Kekuatan perusahaan tidak hanya terletak pada modal perusahaan berupa tangible assets tetapi adanya pengakuan bahwa aset perusahaan berupa pengetahuan (knowledge) dari setiap sumber daya manusia (SDM) yang ada 
dalam perusahaan merupakan aset yang paling berharga. Keberhasilan menciptakan nilai dari suatu produk bukan terletak pada pabrik dan bangunan tapi terletak pada pikiran manusia yang menciptakan nilai produk tersebut (Sir, 2010).

Beberapa penjelasan dari tiga elemen utama IC yaitu:

\section{Human Capital}

Human capital merepresentasikan individual knowledge stock suatu organisasi yang direpresentasikan oleh karyawannya. Human capital merupakan kombinasi dari genetic inheritance; education; experience, dan attitude tentang kehidupan dan bisnis (Bontis, 2001). Human capital akan meningkat apabila perusahaan mampu menggunakan pengetahuan yang dimiliki oleh karyawannya. Brinker (2000) memberikan beberapa karakteritik dasar yang dapat diukur dari modal ini, yaitu training programs, credential, experience, competence, recruitment, mentoring, learning programs, individual potential, and personality.

\section{Structural Capital atau Organizational Capital}

Structural capital merupakan kemampuan organisasi atau perusahaan dalam memenuhi proses rutinitas perusahaan dan strukturnya yang mendukung usaha karyawan untuk menghasilkan kinerja intelektual yang optimal serta kinerja bisnis secara keseluruhan. Termasuk dalam hal ini adalah database, sistem operasional perusahaan, budaya organisasi, dan semua bentuk IC yang dimiliki perusahaan (Bontis, 2001).

\section{Relational Capital atau Customer Capital}

Customer capital didefinisikan sebagai pengetahuan yang berharga yang mengalami interaksi dengan pihak-pihak dari luar organisasi, seperti konsumen, pemasok, kreditor, jaringan, aliansi strategis, jalur distribusi (Bozzolan et al., 2003). Termasuk dalam hal ini adalah citra, reputasi, kesetiaan konsumen, kekuatan komersial, kekuatan negosiasi dengan badan finansial dan kegiatan lingkungan. Customer capital dapat muncul dari berbagai bagian di luar lingkungan perusahaan yang dapat menambah nilai bagi perusahaan tersebut (Bontis, 2001).

\section{Corporate Social Responsibility (CSR) dan Intellectual Capital (IC)}

Berbagai definisi terkait CSR pun telah dijelaskan dalam literatur. Perhatian utama aktivitas CSR adalah terkait isu sosial dan lingkungan yang 
dimasukkan ke dalam praktek bisnis perusahaan untuk merespon masalahmasalah sosial. Sementara itu, salah satu pandangan IC yang berbasis sumber daya menyatakan bahwa perusahaan terdiri dari kumpulan sumber daya dan kemampuan yang berbeda. Fokus utama IC adalah sumber daya yang berupa intangible assets.

Aspek CSR terbagi menjadi 3 kategori yaitu kinerja ekonomi, kinerja lingkungan, dan kinerja sosial. IC meliputi elemen human capital, structural capital, dan customer capital. Kedua aktivitas tersebut diharapkan dapat dimasukkan dalam aktivitas bisnis perusahaan dan dapat menciptakan nilai tambah.

Pedrini (2007) menunjukkan hubungan antara CSR dan IC dalam tabel 1. Dari tabel, dapat dilihat bahwa manfaat aktivitas CSR berdampak terhadap IC. Misalnya, manfaat peningkatan keterampilan dan kompetensi melalui kegiatan pelatihan berdampak pada pelatihan karyawan. Di mana pelatihan karyawan termasuk dalam elemen human capital.

Tabel 1

Hubungan antara CSR dan IC

\begin{tabular}{|c|c|c|}
\hline \multirow{12}{*}{ 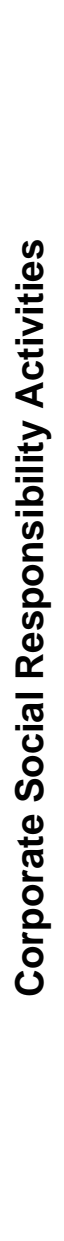 } & Manfaat Aktivitas CSR & $\begin{array}{l}\text { Dampak terhadap } \\
\text { Intellectual Capital } \\
\text { Human Capital }\end{array}$ \\
\hline & $\begin{array}{l}\text { Meningkatkan motivasi } \\
\text { Meningkatkan keterampilan dan kompetensi } \\
\text { melalui kegiatan pelatihan }\end{array}$ & Pelatihan karyawan \\
\hline & $\begin{array}{l}\text { Meningkatkan loyalitas } \\
\text { Meningkatkan keselamatan dan kesehatan } \\
\text { Meningkatkan manfaat karyawan } \\
\text { Menarik personel berkualitas } \\
\end{array}$ & $\begin{array}{l}\text { Kesejahteraan } \\
\text { karyawan }\end{array}$ \\
\hline & & $\begin{array}{l}\text { Organizational } \\
\text { Capital }\end{array}$ \\
\hline & $\begin{array}{l}\text { Peningkatan pengungkapan sukarela } \\
\text { Peningkatan kualitas proses } \\
\text { Perbaikan sistem komunikasi internal }\end{array}$ & Proses manajemen \\
\hline & \begin{tabular}{|l|} 
Proaktif manajemen resiko \\
Meningkatkan tingkat transparansi perusahaan
\end{tabular} & $\begin{array}{l}\text { Corporate } \\
\text { Governance }\end{array}$ \\
\hline & $\begin{array}{l}\text { Reposisi merek } \\
\text { Peninjauan kembali strategi kompetitif } \\
\text { Memanajemen seperangkat hubungan } \\
\text { stakeholder }\end{array}$ & Strategi \\
\hline & $\begin{array}{l}\text { Perubahan budaya perusahaan } \\
\text { Meningkatkan komitmen organisasi }\end{array}$ & Budaya \\
\hline & Peningkatan lingkungan kegiatan $R$ \& D & $R \& D$ \\
\hline & & Relational Capital \\
\hline & $\begin{array}{l}\text { Meningkatkan reputasi perusahaan (sosial, } \\
\text { keuangan, dan sebagainya) }\end{array}$ & Brand image \\
\hline & Memperoleh klien baru & Customer \\
\hline
\end{tabular}




\begin{tabular}{|l|l|l|}
\hline & Meningkatkan loyalitas pelanggan & \\
Memperbesar co-creation & Supplier \\
\cline { 2 - 3 } & Meningkatkan reputasi perusahaan & \\
Memperkuat kerjasama & Peningkatan etika pemasok serta kinerja dan \\
profil sosial & \\
\hline $\begin{array}{l}\text { Meningkatkan reputasi perusahaan } \\
\text { Meningkatkan perhatian investor } \\
\text { Meningkatkan perhatian analis keuangan } \\
\text { Kepercayaan pasar yang lebih baik } \\
\text { Akses ke indeks etis }\end{array}$ & \\
\hline
\end{tabular}

Sumber: Pedrini (2007).

Corporate Social Responsibility (CSR), Intellectual Capital (IC), dan Penciptaan Nilai Tambah.

Tujuan penciptaan nilai CSR dan IC oleh perusahaan dilakukan dengan melibatkan berbagai pihak. Untuk menciptakan nilai tersebut diperlukan pemahaman yang baik tentang bagaimana perusahaan dapat memahami kebutuhan pihak internal seperti karyawan, pihak eksternal seperti konsumen dan masyarakat sekitar perusahaan. Pemahaman yang baik tentang nilai-nilai tersebut dan perusahaan dapat meningkatkan kinerja perusahaan.

Penilaian tentang nilai tambah CSR dan IC masih dalam masa perkembangan. Misal, dalam CSR, instansi seperti WWF-UK yang bekerja sama dengan Cable dan Wireless menunjukkan gambaran keuntungan dan ringkasan sejumlah konsep manajemen yang terkait CSR yang berguna dalam membangun bisnis (Kemp, 2001:34).

Sudrajat (2010) menjelaskan bahwa nilai tambah merupakan peningkatan kekayaan yang dihasilkan oleh penggunaan sumber daya perusahaan secara produktif sebelum dialokasikan di antara para pemegang saham, pemegang obligasi, pekerja dan pemerintah. Sementara Mulawarman (2009) menunjukkan beberapa definisi mengenai nilai tambah dari beberapa literatur antara lain: "Value added adalah perbedaan antara nilai dari output suatu perusahaan atau suatu industri, yaitu total pendapatan yang diterima dari penjualan output tersebut, dan biaya masukan dari bahan-bahan mentah, komponen-komponen atau jasa-jasa yang dibeli untuk memproduksi komponen tersebut. Value added adalah nilai yang ditambahkan oleh suatu perusahaan ke bahan-bahan dan jasajasa yang dibelinya melalui produksi dan usaha-usaha pemasarannya" (Kamus Lengkap Ekonomi Collins, 1994). ... sebagai nilai tambah perusahaan, seperti 
penciptaan nilai dari aktivitas perusahaan dan para karyawannya, yang dapat diukur dengan membedakan antara nilai pasar dari barang yang diputar oleh perusahaan dan biaya dari barang dan material yang dibeli dari perusahaan (producer) lainnya. Pengukuran ini akan mengeluarkan kontribusi yang dibuat oleh perusahaan lain pada nilai total produksi perusahaan, sehingga sebenarnya Value added secara esensial sama dengan penciptaan nilai pasar oleh perusahaan" (Staden, 2002).

Menurut Sudrajat (2010), laporan nilai tambah memiliki beberapa keuntungan antara lain:

1. Nilai tambah memberikan kepuasan kepada para karyawan karena para karyawan mengetahui nilai dari kontribusi yang mereka berikan kepada kekayaan total perusahaan.

2. Nilai tambah mencerminkan dasar penghitungan bonus bagi para pekerja yang lebih baik.

3. Informasi nilai tambah telah terbukti dapat menjadi prediktor peristiwa ekonomi dan reaksi pasar yang baik.

4. Nilai tambah bermanfaat bagi kelompok karyawan karena dapat mempengaruhi aspirasi dan pikiran dari para perwakilannya dalam serikat pekerja yang melakukan negosiasi.

5. Nilai tambah bermanfaat dalam analisis keuangan yaitu dengan menghubungkan beragam peristiwa penting terhadap variabel-variabel nilai tambah.

Nilai tambah CSR dan IC diharapkan tidak hanya menjadi alat untuk mengukur alokasi modal yaitu agar perusahaan tidak selalu melakukan orientasi usahanya untuk memaksimalkan kekayaan para shareholder. Mengingat stakeholders perusahaan tidak hanya terdiri dari shareholders semata. Nilai tambah tersebut dipandang sebagai peningkatan total nilai tambah perusahaan yaitu kinerja ekonomi, nilai reputasi, keunggulan parenting, dan nilai spiritual.

\section{Menciptakan Nilai Ekonomi Melalui CSR dan IC}

Secara historis, profit telah menjadi indikator kunci suatu kinerja ekonomi perusahaan. Dua pengukuran pengembalian yang sering dikenal adalah Return on Equity (ROE) dan Return on Investment (ROI). Pengukuran tersebut tidak memberikan indikasi yang jelas apakah perusahaan benar-benar menciptakan nilai. 
Menurut Kim dan Erik (2003), metode yang terkenal untuk menciptakan nilai ekonomi adalah Economic Value Added (EVA). Nilai tambah aspek-aspek CSR ditunjukkan dalam Gambar 1.

Tabel 2

Formula EVA CSR

\begin{tabular}{|l|}
\multicolumn{1}{|c|}{$\underline{\text { Aspek }}$} \\
Capital (fixed capital) \\
People (employees) \\
Planet (raw material \\
use)
\end{tabular}

\begin{tabular}{|c|c|c|c|}
\hline \multicolumn{4}{|c|}{ Formulasi } \\
\hline $\begin{aligned} \mathrm{EVA}= & (\mathrm{ROCE} \\
& \text { Return on } \\
& \text { Capital } \\
& \text { Employed }\end{aligned}$ & $\begin{array}{l}-\mathrm{CoC}) * \\
\text { Cost } \\
\text { of Capital }\end{array}$ & $\begin{array}{l}\text { CE } \\
\text { Capi } \\
\text { Emp }\end{array}$ & tal \\
\hline $\begin{aligned} \mathrm{EVA}= & (\mathrm{VA} / \mathrm{FTE} \\
& \text { Value added } \\
& \text { Per FTE }\end{aligned}$ & $\begin{array}{l}-\quad \text { C / FTE } \\
\text { Cost per } \\
\text { FTE }\end{array}$ & E) & $\begin{array}{ll}* & \text { FTE } \\
\text { Number of } \\
\text { FTE }\end{array}$ \\
\hline $\begin{aligned} \mathrm{EVA}= & (\mathrm{VA} / \text { ton } \\
& \text { Value added } \\
& \text { per ton raw } \\
& \text { material }\end{aligned}$ & $\begin{array}{l}\text { C / ton) } \\
\text { Cost per } \\
\text { ton raw } \\
\text { material }\end{array}$ & & $\begin{array}{l}\text { ton } \\
\text { ton raw } \\
\text { material } \\
\text { used }\end{array}$ \\
\hline
\end{tabular}

CSR terdiri dari tiga aspek, yaitu capital, people, dan planet. Aspek tersebut digunakan untuk menciptakan nilai perusahaan. Gambar 1 merupakan tahapan sederhana untuk mengaplikasikan EVA.

Sementara IC menggunakan kalkulasi metode Value Added Intellectual Capital (VAIC). VAIC terdiri dari beberapa tahap (Zeghal dan Anis, 2010):

1. Tahap pertama adalah mengkalkulasi kemampuan perusahaan untuk penciptaan nilai tambah. VA dikalkulasikan sebagai berikut:

$$
\text { VA }=\text { OUT - IN }
$$

Outputs (OUT) merepresentasikan pendapatan dan membandingkan semua produk dan jasa yang terjual di pasar; inputs (IN) termasuk semua beban untuk operasi perusahaan, selain beban karyawan.

2. Tahap kedua adalah menilai hubungan antara VA dan Human Capital (HC). The Value Added Human Capital Coefficient (VAHU) mengindikasikan berapa banyak VA diciptakan oleh satu unit keuangan yang diinvestasikan dalam karyawan. VAHU dikalkulasikan sebagai berikut:

$$
\mathrm{VAHU}=\mathrm{VA} / \mathrm{HC}
$$


3. Tahap ketiga menemukan hubungan antara VA dan Structural Capital (SC). The Value Added Structural Capital Coefficient (STVA) menunjukkan kontribusi SC dalam penciptaan nilai. STVA dikalkulasikan sebagai berikut:

$$
\text { STVA = SC / VA }
$$

4. Tahap keempat adalah mengkalkulasi the Value Added Intellectual Capital Coefficient (VAIN), yang menunjukkan kontribusi IC dalam penciptaan nilai. VAIN dikalkulasikan sebagai berikut:

$$
\text { VAIN }=\text { VAHU + STVA }
$$

5. Tahap kelima menilai hubungan antara VA dan Physical and Financial Capital Employed (CA). The Value Added Capital Employed Coefficient (VACA) menyiratkan berapa banyak nilai baru telah diciptakan oleh satu unit moneter dalam capital employed. VACA dikalkulasikan sebagai berikut:

$$
\mathrm{VACA}=\mathrm{VA} / \mathrm{CA}
$$

6. Tahap keenam adalah menilai tiap-tiap sumber yang membantu untuk menciptakan atau memproduksi VA. VAIC mengukur berapa banyak nilai baru telah diciptakan per investasi unit moneter tiap-tiap sumber. VAIC dikalkulasikan sebagai berikut:

$$
\text { VAIC }=\text { VAIN + VACA }
$$

\section{Menciptakan Nilai Reputasi Melalui CSR dan IC}

Reputasi perusahaan merupakan sesuatu yang intangible tetapi dapat dirasakan. Definisi reputasi menurut Srivastava et al., dalam Kim dan Erik (2003) merupakan hasil bersih interaksi dari semua pengalaman, keyakinan, perasaan dan pengetahuan yang dimiliki stakeholder tentang kinerja perusahaan. Reputasi didasarkan pada masa lalu tetapi itu mencerminkan harapan stakeholder tentang kualitas dan kinerja masa depan perusahaan. Dalam hal ini, reputasi menjamin keberlanjutan dan kesuksesan akses ke pasar (baik bagi pelanggan, karyawan atau modal) di mana perusahaan aktif.

Reputasi hari ini mempengaruhi kinerja mendatang. Hal ini tidak mengherankan, beberapa penelitian menunjukkan bahwa reputasi perusahaan diterjemahkan ke dalam nilai finansial. Hal ini telah ditunjukkan secara statistik bahwa $60 \%$ peningkatan reputasi berkorelasi dengan $7 \%$ kenaikan nilai pasar (Kim dan Erik, 2003).

Nilai tambah reputasi dapat dikuantifikasi dengan harga saham (Kim dan Erik, 2003). Menurut Kim dan Erik (2003), harga saham perusahaan merupakan 
hasil (kuantitatif) bersih dari interaksi semua pengalaman, kesan, keyakinan, perasaan dan pengetahuan pemegang saham tentang kinerja perusahaan.

Beberapa studi sebelumnya menunjukkan bahwa pengungkapan CSR dan IC berpengaruh terhadap reaksi investor dilihat dari harga saham dengan proksi abnormal return dan volume perdagangan saham. Pengungkapan CSR berdampak terhadap reaksi investor ditunjukkan oleh Frankental (2001), Raar (2004), Baron (2005), Rute et al., (2005), Zuhroh dan Sukmawati (2003), Cetindamar dan Husoy (2007), Lopez et al., (2007) dan Yuliana et al., (2008). Mereka menguji reaksi investor khususnya abnormal return dan trading volume activity. Pengamatan atas reaksi investor dilakukan selama 11 hari, yaitu 5 hari sebelum dan 5 hari setelah publikasi laporan tahunan. Sementara penelitian yang terkait dengan pengungkapan IC terhadap abnormal return masih terbatas. Sementara Healy et al., (1999) menyatakan bahwa pengungkapan sukarela dapat meningkatkan kinerja saham. Dedman et al., (2008) menemukan bahwa pengungkapan sukarela melalui pengungkapan informasi R\&D secara signifikan berdampak pada reaksi pasar atas harga saham, sehingga dapat diperoleh abnormal return. Sir (2010) menyatakan bahwa pengungkapan IC berdampak pada abnormal return.

Selain mengukur reputasi dengan harga saham, Kim dan Erik (2003) menyatakan upaya lain untuk mengukur reputasi perusahaan dengan menggunakan "Reputasi Quotient", yang dikembangkan oleh Institut Reputasi. Reputasi Quotient merupakan kumulatif hasil jawaban orang dari 20 pertanyaan dalam enam kategori, yang ditunjukkan pada Gambar 2. Indikasi pertama dilakukan di USA di mana ditemukan beberapa kekuatan driver reputasi. Dalam literatur yang ada, reputasi quotient relevan dengan CSR. Akan tetapi reputasi quotient juga dapat dipakai oleh IC. 


\section{Gambar 1 \\ Enam Topik yang Mendefinisikan Reputasi Quotient}

- $\quad$ Stand behind product

- High quality

\section{Product \&}

Services

- Innovative

- Treats people wel

- $\quad$ Supports good causes

- Environmental

Social

Responsibil-

ity responsibility

- $\quad$ Good place to wor

- Well managed

- Good employees

\section{Workplace Environmen}

Financial

Performance

Vision \&

Leadership

Sumber: Kim \& Erik (2003).

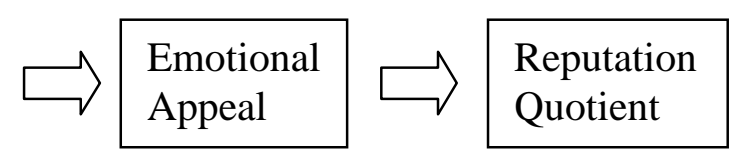

\section{Menciptakan Keunggulan Parenting Melalui CSR dan IC}

Keunggulan parenting dikenal sebagai strategi perusahaan. Banyak perbedaan

konsep strategi perusahaan yang ada. Konsep keunggulan parenting berisi sebagian besar aspek yang diperkirakan relevan untuk strategi perusahaan. Menurut Kim dan Erik (2003), keunggulan parenting berkaitan dengan fakta bahwa perusahaan seharusnya tidak hanya menjadi induk yang baik, tetapi menjadi induk yang terbaik untuk setiap bisnis tertentu.

Empat sumber keunggulan parenting dapat dibedakan sebagai berikut (Goold et al., dalam Moore dan Grete, 2005):

- Pengaruh stand-alone: induk perusahaan mempengaruhi strategi dan kinerja masing-masing bisnis kepemilikan induk dengan melihat masing-masing sebagai profit center yang berdiri sendiri.

- Pengaruh linkage: induk perusahaan berusaha untuk menciptakan nilai dengan meningkatkan hubungan yang ada antara dan sepanjang unit bisnis yang dimilikinya. 
- Pusat fungsi dan layanan: fungsi staf induk perusahaan dan layanan yang menciptakan nilai dengan menyediakan kepemimpinan fungsional dan penghematan biaya layanan untuk bisnis.

- Pengembangan perusahaan: induk dapat mengubah jumlah usaha dalam portofolionya dengan membeli, menciptakan dan menjual bisnis baru. Oleh karena itu, induk dapat membuat (dan menghancurkan) nilai perusahaan melalui kegiatan tersebut. Nilai tersebut berbeda dari yang mungkin kemudian diciptakan melalui pengaruh induk yang sedang berlangsung.

Gambar 3 mengilustrasikan sejumlah driver keunggulan parenting. CSR dapat membuat keunggulan parenting dalam dua cara. Pertama, berdampak pada beberapa driver dalam Gambar 3. Kedua, CSR dapat membantu menciptakan keunggulan parenting melalui penggabungan portofolio model bisnis. Dalam literatur, empat sumber keunggulan parenting relevan dengan CSR. Akan tetapi keunggulan parenting juga dapat dipakai oleh IC.

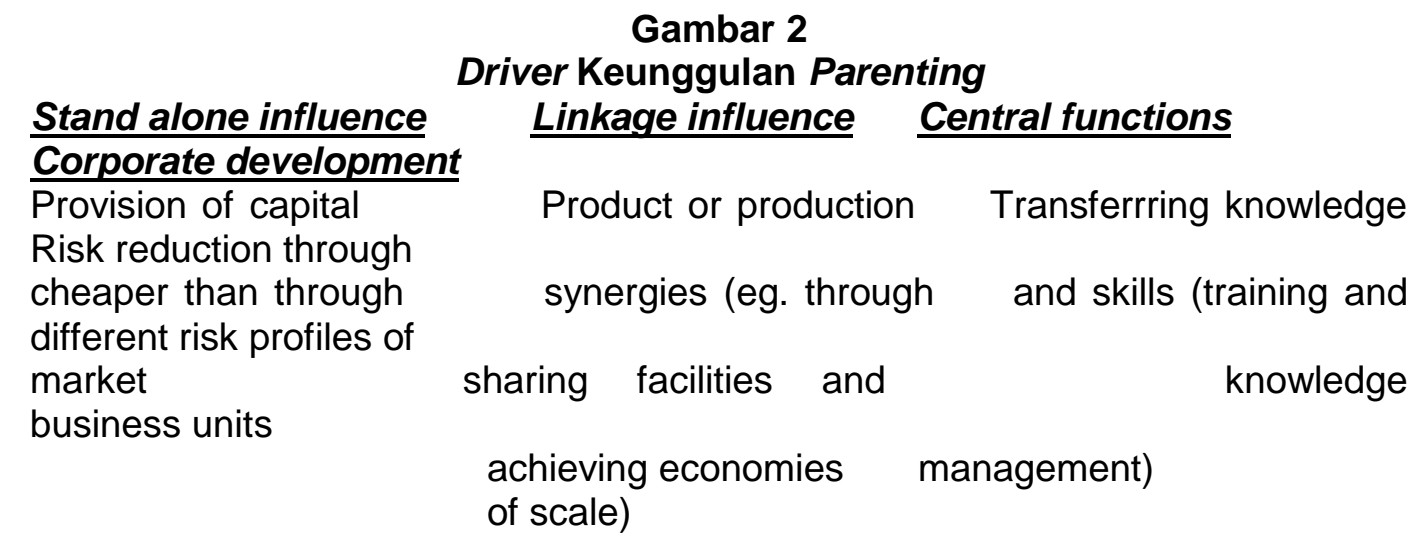

Realisation of Investments and opportunities for divestitures of business restructuring units

Purcashing synergies Better use of infra(increased purchasing structure through power) sharing (eg. reporting)

Sumber: Kim \& Erik (2003).

Menciptakan Nilai Spiritual Melalui CSR dan IC 
Model spiritual company saat ini banyak mempengaruhi perusahaan baik Barat maupun Indonesia. Model-model spiritual yang ada memiliki tujuan yang sama yaitu untuk mencapai going concern perusahaan dengan mengadaptasi nilai-nilai universal berbagai agama yang memiliki kesamaan dan bersifat langgeng, seperti kejujuran, ketulusan, rendah hati, menghargai harkat kemanusiaan, rela berkorban demi kemashlahatan orang banyak, dan sebagainya.

Pesatnya penggunaan spiritualitas dalam perusahaan di samping untuk mempertahankan kemapanan perusahaan juga dapat memberikan kenyamanan bekerja bagi perusahaan. Kenyamanan karyawan menyiratkan pemahaman kepada mereka bahwa bekerja bukan lagi sekedar untuk mencari nafkah atau bersosialisasi, melainkan ingin memberikan sesuatu yang bermakna bagi kehidupan. Mulai dari memberikan makna bagi teman sekerja, perusahaan, pelanggan, pemegang saham, pemerintah, bahkan bagi masyarakat sekitar perusahaan ataupun masyarakat luas (Mulawarman, 2008).

Kepentingan akhir spiritualitas dalam perusahaan menurut tim riset SWA dalam Mulawarman (2008) adalah untuk menghasilkan nilai-nilai organisasi (Value Based Organization) dengan output sebagai berikut:

1. Menghasilkan perubahan sikap individu (seperti pencarian makna lebih pada pekerjaan pada karyawan, orientasi pada memberi/pelayanan pada orang lain).

2. Menurunkan praktek penyelewengan dan pelanggaran wewenang (fraud).

3. Meningkatkan citra atau kredibilitas perusahaan di mata stakeholder.

4. Mendongkrak performa perusahaan secara berkelanjutan.

CSR dan IC secara umum menyatakan bahwa social dan IC cost yang dibayar oleh komunitas harus dikompensasi dengan social dan IC benefit yang diberikan perusahaan kepada komunitas. Nilai tambah spiritual CSR dan IC yang dilakukan oleh perusahaan dilihat sebagai manfaat bukan biaya. Kegiatan tersebut merupakan sebuah nilai charity (Hassan \& Hjh, 2009). Gambar 4 menunjukkan nilai tambah spiritual yang dicerminkan dalam Laporan Laba/Rugi perusahaan. 


\section{Gambar 3}

Nilai Spiritual

Pendapatan

Laporan Laba Rugi

Biaya

Laba Kotor

Pendapatan lainnya

Biaya lainnya

EBIT (Earning Before Interest \& Tax)

Pajak

EAIT (Earning After Interest \& Tax)

Charity

Laba bersih

$X X X$

$\frac{(X X X)}{X X X}$

$X X X$

$\frac{(X X X)}{X X X}$

$X X X$

$\frac{(X X X)}{X X X}$

$\mathrm{XXX}$

$\underline{(X X X)}$

Sumber: Data diolah.

$\mathrm{XXX}$

Nilai spiritual merupakan alat untuk memberikan keseimbangan nilai lebih ekonomi, sosial dan lingkungan bagi setiap individu dalam perusahaan. Para individu tersebut diharapkan memiliki pandangan bahwa pencapaian nilai tambah tidak hanya dalam ukuran ekonomi, tetapi juga berhubungan dengan ukuran sosial dan lingkungan. Aliran kas yang diperoleh dari penerapan nilai spiritual bukan meletakkan aliran kas yang keutamaannya untuk penilaian nilai tambah dalam bentuk ekonomi, tetapi juga aliran kas sosial dan lingkungan itu sendiri (Mulawarman, 2008). Jadi, nilai-nilai spiritual bukan alat untuk menetapkan tujuan perusahaan dalam peningkatan ekonomi semata.

\section{PENUTUP}

CSR dan IC merupakan proses penciptaan nilai dari berbagai stakeholder di mana tuntutan dan harapan akan penciptaan nilai dapat dimasukkan ke dalam keputusan bisnis perusahaan. Tuntutan dan harapan dari berbagai stakeholders tersebut melahirkan nilai tambah CSR dan IC. Nilai tambah CSR dan IC berdasarkan perspektif four value assessment menggunakan formula Economic Value Added (EVA) untuk CSR dan Value Added Intellectual Capital (VAIC) untuk IC, nilai reputasi menggunakan harga saham dan reputation quotient, keunggulan parenting menggunakan strategi perusahaan, dan nilai spiritual menggunakan charity value.

\section{DAFTAR PUSTAKA}


Anggraini, Fr. R. R. 2006. Pengungkapan Informasi Sosial dan Faktor-Faktor yang Mempengaruhi Pengungkapan Informasi Sosial dalam Laporan Keuangan Tahunan (Studi Empiris pada Perusahaan-Perusahaan yang terdaftar Bursa Efek Jakarta). Simposium Nasional Akuntansi IX. Padang

Baron, D. 2005. Corporate Social Responsibility and Social Enterpreneurship. Research Paper No. 1916: Stanford Graduate School of Business.

Belkaoui, A. 2003. Intellectual Capital and Firm Performance of US Multinational Firms: A Study of Resource-Based and Stakeholder Views. Journal of Intellectual Capital 4 (2) 215-226.

Bollen, L., P, Vergauwen., \& S, Schnieders. 2005. Linking Intellectual Capital and Intellectual Property to Company Performance. Management Decision, 43 (9) 1161-1185.

Bontis, N. 1998. Intellectual Capital: An Exploratory Study That Develops Measures and Models. Management Decision, 36 (2) 63-76.

Bontis, N. 2001. Assessing Knowledge Assets: A review of The Models Used to Measure Intellectual Capital. International Journal of Management Reviews, 3 (3) 41-60.

Bozzolan, S., F, Favotto., \& F, Ricerri. 2003. Italian Annual Intellectual Capital Disclosure. Journal of Intellectual Capital, 4 (4) 543-558.

Brinker, B. 2000. Intellectual Capital: Tomorrows Asset, Today's Challenge (Online) Tersedia http://www.cpavision.org/vision/wpaper05b.cfm

Budiarsi, S. Y. 2005. Corporate Sustainability: Melalui Pendekatan Corporate Social Responsibility. Media Ekonomi, Tahun XIV (2) 115-135.

Cetindamar, D., \& Husoy, K. 2007. Corporate Social Responsibility Practices and Environmentally Responsible Behaviour: The Case of The United Nations Global Compact. Journal of Business Ethics, 76: 163-176.

Dedman, E. S, Lin, S. W-J, Prakash, A. J., \& Chang, Chun-Hao. 2008. Voluntary Disclosure and Its Impact on Share Prices: Evidence from the UK Biotechnology Sector. Journal of Accounting and Public Policy, 27 (3) 1-36.

Frankental, P. 2001. Corporate Social Responsibility - APR Invention?. Corporate Communications: An International Journal, 6 (1) 18-23.

Global Reporting Initiatives (GRI). 2006. Sustainability Reporting Guidenlines. Boston: GRI CERES.

Gray, R., Kouhy, R., \& Lavers, S. 1995. Corporate Sosial And Environmental Reporting: A Review Of The Literature And A Longitudinal Study Of UK Disclosure. Accounting, Auditing \& Accountability Journal, 8 (2) 47-77.

Guthrie, J., Petty, R., Yongvanich, K. \& Ricceri, F. 2004. Using Content Analysis as a Research Method to Inquire Into Intellectual Capital Reporting. Journal of Intellectual Capital, 5 (2) 282-293. 
Hassan, A., \& Hjh, S. B. A. L. 2009. Corporate Social Resposibility of Islamic Financial Institutions and Businesses Optimizing Charity Value. Humanomics, 25 (3) 177-188.

Healy, P. M., \& K, G. Palepu. 1993. The Effect of Firms' Financial Disclosure Strategies on Stock Prices. Accounting Horizons, 7 (1) 1-11.

Kemp, V. 2001. To Whose Profit ? Building a Business Case For Sustainability. WWF-UK.

Kim, R., \& Erik, V. D. 2003. The Added Value of Corporate Social Resposibility. Working Paper.

Lopez, M., A, Garcia., \& L, Rodriguez. 2007. Sustainable Development and Corporate Performance: A Study Based on The Dow Jones Sustainability Index. Journal of Business Ethics, 75: 285-300.

Moore, C. M., \& Grete, B. 2005. The Nature of Parenting Advantage in Luxury Fashion Retailing - The Case of Gucci Group NV. International Journal of Retail \& Distribution Management, 33 (4) 256-270.

Mouritsen, J., Larsen, H.T., \& Bukh, P. N. D. 2001. Intellectual Capital and The 'Capable Firm': Narrating, Visualising and Numbering for Managing Knowledge. Accounting, Organization, and Society, 26 (7-8) 735-762.

Mulawarman, A. D. 2008. ESQ Berbasis Spiritual Company: Untuk Kepentingan Siapa?.http://islamic-accounting.blogspot.com/2008/08/sq-berbasisspiritual-company untuk.html.

Mulawarman, A. D.2009. Konsep Nilai Tambah Syariah. (On-line) Tersedia http://www. google.com.

Parker, L. D. 2007. Financial and External Reporting Research: The Broadening Corporate Governance Challenge. Accounting and Business Research, 37 (1) $39-54$.

Pedrini, M. 2007. Human Capital Convergences in Intellectual Capital and Sustainability Reports. Journal of Intellectual Capital, 8 (2) 346-366.

Raar, J. 2004. Environmental and Social Responsibility: A Normative Financial Reporting Concept. Accepted For Presentation at The Fourth Asia Pacific Interdisciplinary Research in Accounting Conference, Singapore.

Rajafi, L. R. 2007. Analisis Pengungkapan Laporan Sosial dan Lingkungan Sebagai Bagian dari Triple Bottom Line Reporting dalam Akuntansi Pertanggungjawaban Sosial Perusahaan: Studi Perbandingan Rata-Rata Tema Pengungkapan Antar Kelompok Industri yang Telah Terdaftar di Bursa Efek Jakarta Tahun 2005. Tidak Dipublikasikan Skripsi S1, Fakultas Ekonomi Universitas Brawijaya, Malang.

Rute, A., F, David, \& D, Crowther. 2005. Corporate Social Responsibility in Portugal: Empirical Evidence of Corporate Behaviour. Corporate Governance, 5 (5) 3-18. 
Sir, J. S. 2010. Intellectual Capital dan Abnormal Return Saham: Studi Peristiwa pada Perusahaan Publik di Bursa Efek Indonesia. Tidak Dipublikasikan Draft Tesis Program Magister Akuntansi Fakultas Ekonomi Universitas Brawijaya, Malang.

Sudrajat, M.A. 2010. Pengungkapan/Disclosure. (On-line). Tersedia www. google.com.

Wright, P. M., Dunford, B. B., \& Snell, S. A. 2001. Human Resource and The Resource Based View of The Firm. Jounal of Management, 27 (6) 701721.

Yuliana, R., Purnomosidhi, B \&. Sukoharsono, E. G. 2008. Pengaruh Karakteristik Perusahaan terhadap Pengungkapan Corporate Social Responsibility (CSR) dan Dampaknya Terhadap Reaksi Investor. Jurnal Akuntansi dan Keuangan Indonesia, 5 (2) 245-276.

Zeghal, D., \& Anis, M.2010. Analysing Value Added as an Indicator of Intellectual Capital and Its Consequences on Company Performance. Journal of Intellectual Capital, 11 (1) 39-60.

Zuhroh, D., \& Sukmawati, I.. 2003. Analisis Pengaruh Luas Pengungkapan Sosial dalam Laporan Tahunan Perusahaan terhadap Reaksi Investor (Studi Kasus pada Perusahaan-Perusahaan High Profile di BEJ). Simposium Nasional Akuntansi VI. Surabaya: 1314-1341 